\title{
Influence of Salicylic Acid on the Antimicrobial Potential of Stevia (Stevia rebaudiana Bertoni, Asteraceae) Leaf Extracts against Soybean Seed-Borne Pathogens
}

\author{
Mohammad Sedghi* and Sahar Gholi-Toluie \\ University of Mohaghegh Ardabili, Ardabil, Iran \\ *For correspondence: Email: mosedghi2003@yahoo.com \\ Received: 17 January 2013 \\ Revised accepted: 16 October 2013
}

\begin{abstract}
Purpose: To investigate the effect of salicylic acid (SA) on the antimicrobial profile of Stevia leaf extracts against soybean seed-borne pathogens.

Methods: Stevia seeds were planted in a greenhouse and SA foliar applied after six weeks on the whole plant at concentrations of 0 and $0.1 \mathrm{~g} \mathrm{~L}^{-1}$. The extracts of the plant leaf were separately obtained using four different solvents (water, acetone, ethanol and chloroform), and the oil composition of the extracts determined by gas chromatography-mass spectrophotometry (GC-MS). The antibacterial and antifungal potentials of each of the extracts were examined against 11 selected pathogens responsible for soybean seed and seedling diseases.

Results: Chloroform extracts had the highest amount of a-cadinol, spathulenol, caryophyllene oxide, methyl salicylate and safranal in the SA-treated plants, and were 8, 10, 18, 14 and $11 \%$, respectively, higher than the non-SA treated control. In the anti-microbial tests, chloroform extract exhibited the highest diameter of inhibition zone (max $18 \mathrm{~mm}$ ) against all the tested microorganisms while water extract showed the least effect (max $9 \mathrm{~mm}$ ), with no effect at all on two fungi (Phomopsis spp and Cercospora kikuchii) and two bacteria (Pseudomonas syringae and Xanthomonas campestris). All extracts with or without SA had no effect on Xanthomonas campestris. SA treatment enhanced the antimicrobial potential of all extracts in the pathogenicity test compared with untreated plant extracts. Conclusion: Stevia leaf extract has antimicrobial effect against soybean seed-borne disease if applied on the seed before planting. Application of SA on the Stevia plant substantially enhances the antimicrobial activity of the leaf extract thus affording the seeds greater protection.
\end{abstract}

Keywords: Stevia, Antimicrobial, Salicylic acid, Soybean, Pathogens.

Tropical Journal of Pharmaceutical Research is indexed by Science Citation Index (SciSearch), Scopus, International Pharmaceutical Abstract, Chemical Abstracts, Embase, Index Copernicus, EBSCO, African Index Medicus, JournalSeek, Journal Citation Reports/Science Edition, Directory of Open Access Journals (DOAJ), African Journal Online, Bioline International, Open-J-Gate and Pharmacy Abstracts

\section{INTRODUCTION}

Stevia (Stevia rebaudiana Bertoni) is a slender, small and perennial herb, belongs to Asteraceae family. Its introduction as a natural and noncaloric sweetener has increased the options of available sweeteners, especially for the diabetic population [1]. This plant is a rich source of stevioside that is 100 - 400 times sweeter than sucrose [2, 3]. Stevia is propagated by seed but the seeds have very low germination capacity and therefore there is a need to find some techniques to improve the seed viability.

Besides the use of stevia as a sweetening agent, there are some reports on the antimicrobial activity of leaf extracts that makes it an important medicinal plant [4-6]. Due to the increasing 
emergence of resistant pathogens, scientists have shown increased interest in identifying new phytochemicals to tackle plant diseases. Stevia leaf extracts contain some phytochemicals such as phenols and flavonoids.

Abou-Arab and Abu-Salem [7] evaluated stevia phytochemicals extracted from leaves and callus against some bacterial and fungal pathogens. They used six different solvents for extraction and reported that methanol and acetone extracts had the greatest antibacterial potentials. In addition, chloroform and ethyl acetate extracts had antifungal potential beside two other solvents. Ghosh et al [5] demonstrated that the petroleum ether extract of stevia leaves at a concentration of $250 \mathrm{mg} \mathrm{ml}^{-1}$ completely inhibited the growth of $E$. coli. The highest antifungal and antibacterial indices were observed for the petroleum ether extract. In the experiment by Tadhani and Subash [6], the hexane extract of stevia leaves showed the highest antimicrobial activity.

The objectives of this study were to determine the effect of salicylic acid (SA) on the chemical composition of different solvent extracted stevia leaves and to evaluate the antimicrobial potential of the extracts against soybean seed-borne fungal and bacterial pathogens.

\section{EXPERIMENTAL}

\section{Determination of the effect of salicylic acid (SA) on Stevia leaf extract oil composition}

In order to determine the effect of salicylic acid on the chemical composition of stevia leaf extracts, a factorial experiment was carried out at the greenhouse based on the completely randomized design arrangement with three replications. Treatments were spraying of SA at concentrations of 0 and $0.1 \mathrm{~g} \mathrm{~L}^{-1}$ applied six weeks after seed planting. Stevia seeds were purchased from Keemiya medicinal farm (Boushehr, Iran) and planted in pots. At harvest, the leaves were collected and packed in polyethylene bags and stored at $4{ }^{\circ} \mathrm{C}$ until extraction. Four extraction solvents were used separately in this experiment, namely, water, acetone, ethanol and chloroform.

Hydrodistillation was used for extraction of essential oil of stevia leaves according to Markovic et al [8]. The method described by Jayaraman et al [4] was used for extraction, in which $25 \mathrm{~g}$ of air-dried powder of Stevia leaves was immersed in $100 \mathrm{ml}$ of the extracting in a flask at laboratory temperature and shaken for $48 \mathrm{~h}$ at $150 \mathrm{rpm}$ on an orbital shaker. The suspension was filtered and the filtrate concentrated to dryness at $40{ }^{\circ} \mathrm{C}$ in a hot air oven. The extract was dissolved in $0.25 \%$ dimethyl sulfoxide (DMSO) to a concentration of $100 \mathrm{mg} \mathrm{mL}^{-1}$. Identification of the selected oil components was performed by gas chromatography-mass spectrophotometry (GCMS) as reported previously by Hossain et al [9]. The GC-MS analysis was performed using a Thermofinigan instrument (Thermofinigan, USA) equipped with a silica capillary column ( $30 \mathrm{~m}$ * $0.25 \mathrm{~mm}$ ). Helium gas was used as a carrier gas at a constant flow rate of one $\mathrm{ml} \mathrm{min}^{-1}$. The injector and mass transfer line temperatures were set at 250 and $260{ }^{\circ} \mathrm{C}$, respectively. Identification of compounds of the essential oil was based on GC retention times on capillary column with Xcalibur processor (Thermofinigan, USA) matching of mass spectra with those of standards.

\section{Evaluation of the antimicrobial activity of the extracts}

In order to study the effect of the extracts on soybean seed-borne and seedling pathogens, some bacterial (Xanthomonas campestris and Pseudomonas syringae) and fungal species (Rhizoctonia solani, Pythium aphanidermatum, $P$. debaryanum, $P$. irregular, $P$. myriotylum, $P$. ultimum, Fosarium spp, Phomopsis spp and Cercospora kikuchii) were selected as the test microbes based on their involvement in soy bean seed disease. Screening of extracts for antibacterial effect was performed by applying agar-well diffusion method [5]. Each extracts were made to final concentration of $50 \mathrm{mg} \mathrm{mL}^{-1}$. Wells $(5 \mathrm{~mm})$ were bored in the agar plate and $24 \mathrm{~h}$ old bacteria cultures were seeded onto plate and uniformly spread. Then, stevia extracts were placed in to the wells and plates were incubated at $37{ }^{\circ} \mathrm{C}$ for 24 hours. Antibacterial activity of extracts was determined by measuring the diameter of the inhibition zone (DIZ) only when the inhibition zone diameter was $8 \mathrm{~mm}$ or more. Controls contained only dimethyl sulfoxide (DMSO). All measurements were performed in triplicates.

Potato dextrose agar (PDA) used for antifungal activity of extracts and $50 \mathrm{mg} \mathrm{ml}^{-1}$ of extract was added to the medium. After solidification, a loopful of $48 \mathrm{~h}$ old fungal culture was placed in the center of the plate. Incubation was performed at $25{ }^{\circ} \mathrm{C}$ for 4 days [10]. DMSO was used for control. The growth of the fungal cultures was measured as the diameter of the inhibition zone (DIZ) and compared with respective control plates. All measurements were performed in triplicates. 


\section{Statistical analysis}

After normality test significantly different means were separated at 0.05 probability level by the Least Significant Difference (LSD) test using SAS 9.1 statistical software and demonstrated by standard deviations.

\section{RESULTS}

Effect of salicylic acid (SA) on Stevia leaf extract oil composition

Main and interaction effects of SA treatments and solvent types on the oil composition of stevia leaves were significant. Foliar application of SA had significantly increased the chemical components of the oil in the extract when compared with control (Table 1). The effect of SA was most pronounced in the chloroform extract followed by acetone extract; to the effect was least for the water and ethanol extracts.

Chloroform extracts exhibited the highest amount of $\alpha$-cadinol (2.89\%), spathulenol (2.35 $\%)$, caryophyllene oxide (1.13\%), methyl salicylate $(0.75 \%)$ and safranal $(0.21 \%)$ for the SA-treated plants; these contents are 8, 10, 18, 14 and $11 \%$, respectively, higher than for the appropriate control, i.e., extracts of plants that were not treated with SA.

\section{Antimicrobial activity of the extracts}

The effect of SA and extraction solvent type on antimicrobial activity was significant on diameter of inhibition zone (DIZ). Among the four extracts tested, chloroform extract showed the strongest antimicrobial effect followed by acetone extract (Table 2). The largest zones of inhibition were observed for chloroform extract against Rhizoctonia solani $(17 \mathrm{~mm})$ and Pseudomonas syringae $(18 \mathrm{~mm})$ whose plants were treated with $0.1 \mathrm{~g} \mathrm{~L}^{-1} \mathrm{SA}$. Water extract was not effective against Phomopsis spp, Cercospora kikuchii, Xanthomonas campestris and Pseudomonas syringae including water extracts obtained from plants treated with SA. None of the extracts (including those obtained from plants treated with SA) had any significant effect against Xanthomonas campestris.

Table 1: Effect of salicylic acid on the oil composition of various Stevia leaf extracts

\begin{tabular}{lllllll}
\hline $\begin{array}{c}\text { SA } \\
\left(\mathbf{g ~ L}^{-1} \mathbf{)}\right.\end{array}$ & Solvent & $\begin{array}{l}\mathbf{\alpha} \text {-cadinol } \\
\mathbf{( \% )}\end{array}$ & $\begin{array}{l}\text { Spathulenol } \\
\mathbf{( \% )}\end{array}$ & $\begin{array}{l}\text { Caryophyllene } \\
\text { oxide (\%) }\end{array}$ & $\begin{array}{l}\text { Methyl } \\
\text { salicylate (\%) }\end{array}$ & Safranal (\%) \\
\hline \multirow{4}{*}{0} & Water & $1.24 \pm 0.11$ & $1.08 \pm 0.1$ & $0.69 \pm 0.06$ & $0.32 \pm 0.02$ & - \\
& Acetone & $2.26 \pm 0.11$ & $1.85 \pm 0.1$ & $0.84 \pm 0.06$ & $0.47 \pm 0.02$ & $0.14 \pm 0.01$ \\
& Ethanol & $1.85 \pm 0.11$ & $1.51 \pm 0.1$ & $0.71 \pm 0.06$ & $0.41 \pm 0.02$ & - \\
& Chloroform & $2.68 \pm 0.11$ & $2.13 \pm 0.1$ & $0.96 \pm 0.06$ & $0.66 \pm 0.02$ & $0.19 \pm 0.01$ \\
& Water & $1.37 \pm 0.11$ & $1.22 \pm 0.1$ & $0.78 \pm 0.06$ & $0.37 \pm 0.02$ & - \\
0.1 & Acetone & $2.49 \pm 0.11$ & $1.93 \pm 0.1$ & $0.94 \pm 0.06$ & $0.55 \pm 0.02$ & $0.18 \pm 0.01$ \\
& Ethanol & $1.97 \pm 0.11$ & $1.72 \pm 0.1$ & $0.85 \pm 0.06$ & $0.51 \pm 0.02$ & - \\
& Chloroform & $2.89 \pm 0.11$ & $2.35 \pm 0.1$ & $1.13 \pm 0.06$ & $0.75 \pm 0.02$ & $0.21 \pm 0.01$ \\
\hline
\end{tabular}

Table 2: Effect of salicylic acid and extract type on the diameter of inhibition zone (DIZ, $\mathrm{mm}$ ) of soybean seedborne pathogen cultures

\begin{tabular}{|c|c|c|c|c|c|c|c|c|c|}
\hline \multirow{3}{*}{ Pathogen } & \multicolumn{5}{|c|}{ No SA treatment $\left(0 \mathrm{~g} \mathrm{~L}^{-1}\right)$} & \multicolumn{3}{|c|}{ SA-treated $\left(0.1 \mathrm{~g} \mathrm{~L}^{-1}\right)$} & \multirow{3}{*}{$\begin{array}{l}\text { LSD } \\
(5 \%)\end{array}$} \\
\hline & \multicolumn{8}{|c|}{$\begin{array}{l}\text { Extract type } \\
\end{array}$} & \\
\hline & Water & Acetone & Ethanol & Chloroform & Water & Acetone & Ethanol & Chloroform & \\
\hline $\begin{array}{l}\text { Rhizoctonia } \\
\text { solani }\end{array}$ & 7 & 12 & 6 & 13 & 8 & 14 & 8 & 17 & 0.15 \\
\hline $\begin{array}{l}\text { Pythium } \\
\text { aphanidermatum }\end{array}$ & 5 & 11 & 8 & 12 & 7 & 14 & 9 & 15 & 0.1 \\
\hline P. debaryanum & 6 & 10 & 9 & 11 & 9 & 12 & 10 & 14 & 0.12 \\
\hline P. irregular & 5 & 10 & 8 & 10 & 8 & 12 & 10 & 13 & 0.18 \\
\hline P. myriotylum & 4 & 7 & 7 & 6 & 8 & 11 & 10 & 10 & 0.1 \\
\hline P. ultimum & 7 & 9 & 7 & 10 & 8 & 12 & 9 & 12 & 0.1 \\
\hline Fosarium spp & 5 & 8 & 6 & 9 & 7 & 11 & 8 & 14 & 0.12 \\
\hline Phomopsis spp & - & 10 & 9 & 11 & - & 13 & 10 & 14 & 0.13 \\
\hline $\begin{array}{l}\text { Cercospora } \\
\text { kikuchii }\end{array}$ & - & 9 & 9 & 10 & - & 12 & 12 & 13 & 0.1 \\
\hline $\begin{array}{l}\text { Xanthomonas } \\
\text { campestris }\end{array}$ & - & - & - & - & - & - & - & - & - \\
\hline $\begin{array}{l}\text { Pseudomonas } \\
\text { syringae }\end{array}$ & - & 12 & 10 & 15 & - & 16 & 13 & 18 & 0.13 \\
\hline
\end{tabular}




\section{DISCUSSION}

Salicylic acid is a phenolic compound that regulates some physiological responses in plants and improves its growth even under stress conditions [11]. Spraying of Shara plants (Plectranthus tenuiflorus) with $0.5 \mathrm{mM}$ of SA increased the percentage of oil, terpens and other oil constituents. It has been demonstrated that maintaining balanced growth of plants through SA application is due to effective scavenging of reactive oxygen species (ROS) that cause severe damage to membranes and secondary metabolite synthesis.

Rowshan et al [12] reported a significant increase in the essential oil composition of Salvia macrosiphon by exogenous application of SA at a concentration of $200 \mathrm{mg} \mathrm{L}^{-1}$ and concluded that SA can manipulate essential oil production in the plant. Kazemi and Shirzadeh [13] studied the changes of essential oil components of Rosmarinus officinalis in response to SA and malic acid (MA). They observed that some components of oil increased as a result of SA and MA application but others decreased and endorsed to the manipulation power of these two acids for changing in the essential oil composition. Similar results were observed by Talaat and Balbaa [14] in Ocimum basilicum when putrescine and trans-cynnamic acid (an intermediate in SA biosynthesis) were applied exogenously.

Jayaraman et al [4] found the acetone extract of Stevia leaves showed stronger antimicrobial activity than three other extracts (water, ethyl acetate and chloroform) when tested against microorganisms due to the greater solubility of the extract in acetone. Other workers noted that the water extract of Stevia leaves had no antimicrobial activity $[4,6]$. This finding is in partial agreement with the results of our experiment where it was observed that Xanthomonas campestris, Pseudomonas syringae, Phomopsis spp and Cercospora kikuchii were not affected by water extract. This should be related to the low solubility of the extract in water. Also, it has been reported that water extracts do not have antibacterial effect [4]. On the other hand, growth media probably has important effect on the identification of antibacterial activity. The greater activity of chloroform extracts may be due to the greater stability of active ingredients in the solvent over a long time [4].

Ghosh et al [5] found that petroleum ether extract of Stevia leaves displayed sufficient antimicrobial activity against dreaded animal pathogens. The antifungal activity exhibited by the extracts was higher than those of known plant fungicides such as Zineb, Metalaxyl and Carbendazim. Thus the extracts can be regarded as a bio-fungicide. There are few studies on the antimicrobial effects of Stevia leaf extracts [4-6], especially against soybean seed-borne pathgens.

\section{CONCLUSION}

The findings of this study indicate that application of SA to the whole plant of Stevia increases the content of the bioactive ingredients of plant leaf extracts which, potentially, can be used as a bio-fungicide for soybean seed treatment before planting or storage.

\section{REFERENCES}

1. Ingle MR. Effect of growth regulators and environments on rooting of stevia cuttings (Stevia rebaudiana Bertoni). [Dissertation]. [Dharwad]: University of Agricultural Sciences. 2008; $p 67$

2. Gujral SR. Stevia $0 \%$ Calorie, $100 \%$ Sweet, $100 \%$ Nature. Sci Tech Entrepreneur 2004; 12(10): 1822.

3. Taware AS, Harke SN, Mukadam DS, Chavan AM, Taware SD. Effect of different extracts of callus and plantlets of Stevia rebaudiana (Bertoni) on seed germination of some agricultural crops. African J Biotech 2010; 9(40): 6675-6683.

4. Jayaraman S, Manoharan MS, Illanchezian S. In-vitro Antimicrobial and Antitumor Activities of Stevia Rebaudiana (Asteraceae) Leaf Extracts. Trop J Pharm Res 2008; 7(4): 1143-1149.

5. Ghosh S, Subudh IE, Nayak S. Antimicrobial assay of Stevia rebaudiana Bertoni leaf extracts against 10 pathogens. Int J Integ Biol 2008; 2:27-31.

6. Tadhani BM, Subash R. In Vitro Antimicrobial Activity of Stevia rebaudiana Bertoni Leaves. Trop J Pharm Res 2006; 5(1): 557-560.

7. Abou-Arab EA, Abu-Salem FM. Evaluation of bioactive compounds of Stevia rebaudiana leaves and callus. African J Food Sci 2010; 4(10): 627-634.

8. Markovic IS, Darmati Z, Abramovic B. Chemical composition of the leave extracts of Stavia rebaudiana Bertoni grown experimentally in Vojvodina. J Serb Chem Soc 2008; 73(3): 283-97.

9. Amzad Hossain M, Siddique AB, Mizanur Rahman SM, Amzad Hossain M. Chemical composition of the essential oils of Stevia rebaudiana Bertoni leaves. Asian J Trad Med 2010; 5(2): 56-61.

10. Lindsay EM. Practical Introduction to Microbiology. UK. E \& FN spon Ltd. 1962; $p 177$.

11. Jalal RS, Bafeel SO, Moftah AE. Effect of salicylic acid on growth, photosynthetic pigments and essential oil components of Shara (Plectranthus tenuiflorus) plants grown under drought stress conditions. Int Res J Agric Sci Soil Sci 2012; 2(6): 252-260.

12. Rowshan V, Khosh Khoi M, Javidnia K. Effects of Salicylic Acid on Quality and Quantity of Essential oil Components in Salvia macrosiphon. J Biol Environ Sci 2010; 4(11): 77-82.

13. Kazemi $M$, Shirzadeh $E$. Effect of malic acid and salicylic acid on the quality and quantity of essential oil components in Rosmarinus officinalis. Asian J Biochem 2012; 7(3): 177-181.

14. Talaat IM, Balbaa LK. Physiological response of sweet basil palnts (Ocimum basilicum L.) to ptrescine and trans cinnamic acid. Amer-Eura J Agric Environ Sci 2010; 8(4): 438-445.

Trop J Pharm Res, December 2013;12 (6): 1038 